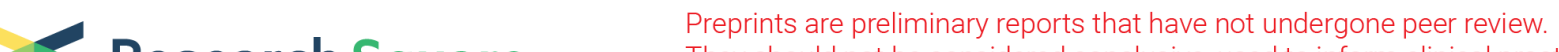 Research Square
or referenced by the media as validated information.
}

\section{Molecular phylogeny based on its sequences of nrDNA ITS of Adonis (Linnaeus, 1753) (Ranunculaceae) from various ecological sites of Turkey}

FARUK KARAHAN ( $\square$ farukkarahan34@gmail.com )

Mustafa Kemal Üniversitesi Fen Edebiyat Fakültesi https://orcid.org/0000-0001-7927-1409

Ahmet İlcim

Hatay MKÜ: Hatay Mustafa Kemal Universitesi

Aras Türkoğlu

Necmettin Erbakan University: Necmettin Erbakan Universitesi

Emre ilhan

Erzurum Technical University: Erzurum Teknik Universitesi

Kamil Haliloğlu

Ataturk University: Ataturk Universitesi

\section{Research Article}

Keywords: Ranunculaceae, pheasant's-eye, endemic, molecular analyses, ITS, Turkey.

Posted Date: February 15th, 2022

DOI: https://doi.org/10.21203/rs.3.rs-1339936/v1

License: (c) (1) This work is licensed under a Creative Commons Attribution 4.0 International License. Read Full License

Version of Record: A version of this preprint was published at Molecular Biology Reports on June 9th, 2022. See the published version at https://doi.org/10.1007/s11033-022-07607-7. 


\section{Abstract}

Background Genus Adonis (Linnaeus, 1753) contains approximately 40 annual and perennial species, which are widely distributed in the temperate zones of Asia and Europe, and less frequently in southwestern Asia, northern Africa and the Mediterranean region. In the present study, molecular phylogeny of genus Adonis L. from Turkey was evaluated with the aid of nrDNA ITS.

Methods Samples of 10 natural Adonis taxa belonging to 21 different populations including 64 Adonis ecotypes were collected from different regions of the country during vegetation period between 2014 and 2018. ITS1, ITS4, P16 and P25 primers within Internal Transcribed Spacer (ITS) technique were used to estimate infraspecific variation in different populations of Adonis species.

Results We identified about 600 bp DNA sequences were obtained from 21 different populations including 64 Adonis ecotypes. The dendrogram obtained from Adonis species and out-group sequences had two large main groups. While the out-group species were placed in the first large main group, the sect. Consiligo (perennial) and sect. Adonis (annuals) were placed in different sub-groups of the second large main group. Genetic similarity among Adonis species varied between $A$. microcarpa and $A$. dentata (98.46\%).

Conclusions Present analyses revealed that phylogenetic classification (grouping) of Adonis taxa largely depended on morphological structure and present ITS primers were quite efficient in putting forth the genetic diversity of such species. The results obtained from molecular data can be used to explore the genetic variation pattern, population structure, and the evolutionary history of natural Adonis species in the future.

\section{Introduction}

Ranunculaceae family, distributed almost all over the world, is considered as one of the essential groups of ancient angiosperms. It is a monophyletic family and estimated to have a history of approximately 75 million years according to the fossil records [1-3]. This family with about 43 genera and 2346 species is represented by 20 genera and 204 species in Turkey and 51 of these species are endemic [4, 5].

Within the family, Adonis L. genus contains approximately 40 annual and perennial species, which are widely distributed in the temperate zones of Asia and Europe, and less frequently in southwestern Asia, northern Africa and the Mediterranean region [6-11]. Adonis species are distributed in habitats such as fallow fields, cultivated fields, industrial areas, airports, railway, highway sides, mountain steppes, forest, meadows, rocky slopes, shrubs, ruins, pastures and altitudes between 0-3500 m. [12]. In the latest taxonomic studies, the genus was divided into 2 sections, annual species in sect. Adonis and perennials in sect. Consiligo DC, and is represented by 11 taxa in Turkey [4, 12-15]. Previous studies on Adonis were mostly restricted to morphological [16, 17], ecological [18], palynological [19] and cytological analyses [20]. Large variations in morphological characteristics and hybridizations between some species are the main problems in identification of Adonis species. Many previous studies reported that molecular 
techniques had great contributions to understanding phylogeny, evolution and taxonomy of Adonis and the other species [21-23]. Recently, Ro et al. [24] investigated phylogenetic relationships among 31 species belonging to Ranunculaceae family distributed in America using ITS regions (26S DNA) and reported that Adonis vernalis and Trollius laxus species were closely related. Johansson [21] studied phylogenetic relationships of Adonis amurensis, A. annua, A. brevistyla, A. cyllenea, A. pyrenaica and $A$. vernalis species with rps16 regions and reported that these species were close relatives and total size of genome was $151.3 \mathrm{~kb}$ in $A$. annua and $156.5 \mathrm{~kb}$ in Adonis vernalis. Suh et al. [25] studied phylogenetic relationships among 60 genotypes and 12 populations belonging to $A$. amurensis, Adonis pseudoamurensis, $A$. multiflora, and $A$. vernalis in Korea based on ITS and $5.8 \mathrm{~S}$ regions in nuclear DNA. In that study, systematic status of $A$. pseudoamurensis taxon, which was previously introduced as a new species based only on morphological data, was supported with the molecular data. Cai et al. [26] studied phylogeny of 82 species including $A$. amurensis, A. multiflora, A. ramosa and A. shikokuensis of Ranunculaceae family widespread in China with the aid of ITS and 5.8S regions. With that study, previously classified sub-families and tribes based on morphological data were revised according to the phylogenetic tree obtained from molecular data. Despite several previous studies, molecular studies on Adonis generally focused on perennial species and the information about phylogeny and genetic diversity of this genus is quite limited. The main objective of this study was to analyze genetic diversity and phylogenetic relationships among and within Adonis genus naturally growing in Turkey based on nrDNA ITS. To the best of our knowledge, our findings reflect the great genetic diversity of Adonis populations and molecular data obtained from this study can be used to explore the genetic variation pattern, population structure, and the evolutionary history of natural Adonis species in the future.

\section{Materials And Methods}

Plant samples

During the field studies for the taxonomic revision of the genus in Turkey, plant samples were collected from 21 natural populations of Adonis L. (A. volgensis Stev. ex DC., A. paryadrica (Boiss.) Kandemir \& Aytaç. A. aleppica Boiss., A. annua L., A. microcarpa DC., A. dentata Del., A. aestivalis L. subsp. aestivalis L., A. aestivalis L. subsp. parviflora (Fisch. ex DC.) Busch., A. eriocalycina Boiss., and A. flammea Jacq.) in different regions between the years 2014 and 2018 (Fig. 1 and Table 1). Botanical identification of all samples was carried out based on the related literature $[4,8,9,13,16,27-35]$. 
Table 1

Sampling locations and geographic distribution of Adonis populations in this study.

\section{No Taxa}

$1 \quad$ A. volgensis 161

2 A. volgensis 167

3 A. paryadrica 179

$4 \quad$ A. paryadrica $\mathrm{K} 10548$

$5 \quad$ A. aleppica 117

$6 \quad$ A. aleppica 141

$7 \quad$ A. annua 123

$8 \quad$ A. annua 143

9 A. microcarpa 102

10 A. microcarpa 122

11 A. dentata 108

12 A. dentata 114

13 A. aestivalis subsp. aestivalis 144

14 A. aestivalis subsp. aestivalis 148

15 A. aestivalis subsp. aestivalis 168

16 A. aestivalis subsp. parviflora 115

17 A. aestivalis subsp. parviflora 129

18 A. eriocalycina 132

19 A. eriocalycina 164

$20 \quad$ A. flammea 135

21 A. flammea 154
Latitude Longitude

Altitude

(m)

$39^{\circ} 76^{\prime} 870^{\prime \prime} \quad 44^{\circ} 14^{\prime} 774^{\prime \prime} \quad 1580$

$40^{\circ} 46^{\prime} 264^{\prime \prime} \quad 42^{\circ} 95^{\prime} 340^{\prime \prime} \quad 1827$

$40^{\circ} 21^{\prime} 289^{\prime \prime} \quad 38^{\circ} 57^{\prime} 439^{\prime \prime} \quad 2276$

$36^{\circ} 60^{\prime} 230^{\prime \prime} \quad 39^{\circ} 09^{\prime} 888^{\prime \prime} \quad 1900$

$37^{\circ} 39^{\prime} 885^{\prime \prime} \quad 38^{\circ} 44^{\prime} 698^{\prime \prime} \quad 576$

$36^{\circ} 93452^{\prime \prime}$

$37^{\circ} 38^{\prime} 829^{\prime \prime}$

$37^{\circ} 53^{\prime} 903^{\prime \prime} \quad 36^{\circ} 82^{\prime} 373^{\prime \prime}$

$36^{\circ} 93^{\prime} 452^{\prime \prime}$

$36^{\circ} 61^{\prime} 688^{\prime \prime}$

$37^{\circ} 53^{\prime} 898^{\prime \prime}$

$36^{\circ} 80^{\prime} 804^{\prime \prime}$

$37^{\circ} 01^{\prime} 059^{\prime \prime}$

$38^{\circ} 27^{\prime} 653^{\prime \prime}$

$38^{\circ} 01^{\prime} 864$

$39^{\circ} 97^{\prime} 982^{\prime \prime}$

$41^{\circ} 47^{\prime} 076^{\prime \prime}$

$37^{\circ} 01^{\prime} 059^{\prime \prime}$

$38^{\circ} 03^{\prime} 994^{\prime \prime}$

494

$37^{\circ} 05^{\prime} 282^{\prime \prime} \quad 38^{\circ} 08^{\prime} 719^{\prime \prime} \quad 554$

$37^{\circ} 37^{\prime} 213^{\prime \prime} \quad 40^{\circ} 70^{\prime} 214^{\prime \prime} \quad 980$

$40^{\circ} 28^{\prime} 104^{\prime \prime} \quad 42^{\circ} 95^{\prime} 687^{\prime \prime} 1820$

$37^{\circ} 37^{\prime} 213^{\prime \prime} \quad 40^{\circ} 70^{\prime} 214^{\prime \prime} \quad 980$

$39^{\circ} 61^{\prime} 516^{\prime \prime} \quad 32^{\circ} 65^{\prime} 337^{\prime \prime} 1063$
Locality

B9 Iğdır: Elmagöl

A9 Kars: Kağızman

A7 Giresun: Alucra

B7 Erzincan: Kemah

C7 Urfa to Bozova road

C6 Antep to Kilis road

C6 Maraş-

Süleymanlı

C6 Antep-Kilis road

C6 Hatay: Kırıkhan

C6 Maraş: Narlı

C6 Kilis to Hassa road

C7 Urfa: Bentbahçesi

B2 Kütahya to Afyon road

B5 Aksaray to Adana road

B8 Erzurum: Pasinler

C7 Urfa: Bentbahçesi

C7 Urfa: Birecik-

Suruç

C8 Mardin: Zinnar

A9 Kars: Kağızman

C8 Mardin: Zinnar

B4 Ankara:

Haymana 
Adonis species should be collected during the growing season since the morphological characteristics such as achene and flower are very important easy to identify (Fig. 2). In our study, morphological analysis was performed based on Flora of Turkey using the following features: flower diameter, sepal shape, sepal width and length, feather in sepal, number of petals, petal shape, petal color, petal width and length, blackish in petal base, aggregate width and length, surface type of achene, achene width and length, hump position, hump shape, hump width and length, beak width and length, beak shape, beak surface and beak color.

DNA extraction, PCR amplification, sequencing

Total genomic DNA from each accession was extracted as previously described by [36]. The quality of DNA was confirmed by electrophoresis in $0.8 \%$ agarose gel, and the DNA concentration was measured using The NanoDrop ${ }^{\circledR}$ ND-1000 UV/Vis spectrophotometer. The final DNA concentration was adjusted to $50 \mathrm{ng} / \mu \mathrm{L}$ for ITS analysis, and the diluted DNA was stored at $-20^{\circ} \mathrm{C}$. PCR reactions were prepared using ITS1 (5'-TCCGTAGGTGAACCTGCGG-3'), ITS4 (5'-TCCTCCGCTTATTGATATGC-3'), P16 (5'CCAYTGAACCTTATCATTKAGAGGA-3') and P25 (5' GGGTAGTCCCGCCTGACCTG-3') primers from previous reports [37-39]. PCR amplifications were performed in a thermal cycler (Labcycler). The PCR mixture consisted of $1 \mathrm{X}$ buffer, $2 \mathrm{mM} \mathrm{MgCl}, 0.25 \mathrm{mM}$ of each dNTP, $1 \mu \mathrm{M}$ (20 pmol) primer, $0.5 \mathrm{U}$ Taq polymerase, and $50 \mathrm{ng} / \mu \mathrm{L}$ DNA template in a $20 \mu \mathrm{L}$ reaction mixture. The amplification conditions were as follows: an initial denaturation step of $3 \mathrm{~min}$ at $95^{\circ} \mathrm{C}, 38 \mathrm{cycles}$ of $60 \mathrm{~s}$ at $95^{\circ} \mathrm{C}, 60 \mathrm{~s}$ at $67^{\circ} \mathrm{C}, 120 \mathrm{~s}$ at $72^{\circ} \mathrm{C}$, and a final extension step of $10 \mathrm{~min}$ at $72^{\circ} \mathrm{C}$. The amplification products were resolved in $1.5 \%$ agarose gel in $1 \mathrm{X}$ SB buffer at $6 \mathrm{~V} / \mathrm{cm}$ for $120 \mathrm{~min}$, stained with ethidium bromide $(0.5 \mathrm{ug} / \mathrm{mL})$, and visualized under a UV-trans illuminator. The sizes of the base pairs were determined based on a DNA ladder between 50 and 1.000 bp (Vivantis Product No: NM2421). PCR products were sequenced using an ABI 3500XL (Applied Biosystems, Foster City, CA, USA) automated sequencer.

Molecular cloning and sequencing

The raw data obtained from the sequencing process were edited using ChromasPro Version 1.7.5 (Technelysium Pty. Ltd. 2003-2013). The sequence alignment was performed on ClustalW 2.1 program [40] and adjusted manually. The phylogenetic tree was constructed using the Neighbor Joining TreeJukes-Cantor model of Geneious V. 11.1.4 program. The phylogenetic tree was visualized using Interactive Tree of Life [41]. Branch support values were calculated using a full heuristic search using maximum number of trees 1000 and 1000 bootstrap replicates. ITS sequences of Ranunculus asiaticus L. (GU257963), Delphinium polycladon Eastw (AF258743), and Adonis vernalis (AJ347910) taxa used as out-group in the phylogenetic tree were retrieved from NCBI GenBank based on related studies [26, 4244].

\section{Results And Discussion}


In this study, about 600 bp DNA regions were obtained from 64 genotypes of 10 Adonis taxa natural distributed in Turkey. The data for investigated Adonis species and out-groups were subjected to genetic distance clustering analysis and resultant dendrogram is presented in Fig. 3.

According to resultant dendrogram, outgroups are clearly different from the examined Adonis species. In dendogram, Adonis members were separated into two large groups based on their genetic distance to each other. In the first large group, Consiligo section including perennial $A$. volgensis and A. paryadrica species was close to perennial out-group taxa A. vernalis, Adonis section composed of annual species was clearly separated from them. In the second large group, annual Adonis species were placed together close to each other. Such a case proved that genotypes of Turkish flora and present Adonis taxa were separated at section-level based on their length of life and general morphology. Considering the annual Adonis section, it was observed that $A$. aleppica, A. microcarpa, $A$. dentata, and $A$. annua) species (from A. aleppica FK117-1 to $A$. annua FK143-2) were placed in the 1st main group of large main groups and the other species (from A. flammea FK135-2 to A. aestivalis subsp. aestivalis FK144-3) were placed in the 2nd main group. A. microcarpa generally has red flowers and rarely has yellow flowers. Red-flower samples were largely close to $A$. annua species). Yellow-flower $A$. microcarpa FK122-4 was very similar morphologically to $A$. dentata, thus was placed in the same group with it. Although yellow-flower forms of this species are weakly monophyletic, such a case should be elucidated with further studies (Fig. 3).

Genetic similarity data were given in supplementary file. There were quite high genetic similarity coefficients between yellow-flower $A$. microcarpa and $A$. dentata $(98.46 \%)$ and they had very close relationships with each other. Morphological characteristics facilitating phylogenetic separation of the taxa are presented in Fig. 3. Genetic distances among Adonis species varied between 1.16-26.43\%. Based on only primers used in this study, the lowest genetic distance ratios were respectively observed as $1.16 \%$ (between A. microcarpa-102 and A. annua-123) and 1.21\% (between A. microcarpa-122 and A. dentata108); the greatest genetic distance ratios were respectively observed as $26.43 \%$ (between $A$. volgensis167 and $A$. aestivalis subsp. aestivalis-144), 26.215 (between A. paryadrica-179 and A. aestivalis subsp. aestivalis-144) and 22.975 (between $A$. aestivalis subsp. parviflora-129 and $A$. volgensis-167). With regard to intraspecific genetic distances, the lowest values were observed in $A$. annua $(0.42 \%), A$. dentata $(0.43 \%)$ and $A$. eriocalycina ( $1.15 \%)$; the greatest values were observed in $A$. aestivalis subsp. aestivalis (19.01\%) and $A$. volgensis (5.02\%). The dendrogram revealed that grouping of the species of the genus largely depended on morphological structure. The A. volgensis and A. paryadrica species of Consiligo section were perennial and they were quite similar in rhizome structure, flower diameter and color, number of petals, aggregate and achene structures. Since $A$. aestivalis sub-species were morphologically similar, they were also in similar phylogenetic grouping. While $A$. aestivalis subsp. aestivalis and $A$. aestivalis subsp. parviflora had similar general morphology, aggregate structure, achene shapes, flower colors and petal stains, they were different in flower diameter, achene sizes and surfaces. $A$. annua and $A$. microcarpa species closely positioned in the dendrogram were similar in hairs, spread zones, flowering periods, non-hairy stems, sepal hairs, flower color, petal stains, achene sequence, size and surface, but different in achene shape, dorsal hump, flower diameter and sepal shape (Fig. 2). 
In this study, intra and inter-species genetic relations of Adonis species were determined with the aid of molecular data gathered from 10 Adonis taxa widespread in Turkey, an out-group Ranunculus asiaticus taxa morphologically close to Adonis and Delphinium polycladon taxa morphologically far from Adonis. In Flora of Turkey [13], based on morphological characteristics, perennial A. volgensis and A. paryadrica species were separated from annual species in number of petals, flower colors and aggregate structures and placed under sect. Consiligo. The present phylogenetic dendrogram also supported such a separation. Heyn and Pazy [20] reported number of chromosomes as $2 n=16$ for $A$. annua and $A$. dentata, as $2 n=32$ for $A$. microcarpa and as $2 n=48$ for $A$. aestivalis. According to the present findings, $A$. annua and $A$. dentata species with the same number of chromosomes were genetically quite close to each other (98.44\% similarity coefficients). In the study of Cai et al. [26] and Wang et al. [42], Adonis species were genetically placed together with Ranunculus species in the same group and separated from Delphinium species. In the present dendrogram, Adonis species were placed at close positions to morphologically close Ranunculus asiaticus species (Fig. 3). In Kandemir et al. [15], the status of the Adonis cyllenea var. paryadrica was re-evaluated and it was decided to change its taxonomic status to species level as $A$. paryadrica according to leafy stems, young carpels more densely pubescent, sepals $1 / 2$ to petals, and tall rhizomatous. In our results, taxonomic status of $A$. paryadrica was supported with molecular data. Fischer et al. [45] indicated increasing gene flow between the populations with decreasing geographical distances. Present dendrogram also revealed high genetic similarities between geographically close populations. For instance, while the genetic similarity of Erzurum population of $A$. aestivalis subsp. aestivalis (FK 168) to geographically close Aksaray population (FK 148) was $90.59 \%$, genetic similarity to further Kütahya population (FK 144) was $84.33 \%$. Mitton and Grant [46] and Bosh et al. [47] indicated the most significant factors threatening endemic and endangered plant species as changing ecological conditions and potential genetic risks resulting from reduced genetic variation [22]. In the present study, genetic similarity between endemic $A$. paryadrica populations close species was quite high. Right at this point, it was proved once again that calculation of genetic variation played a significant role in decisions to be made for the preservation of endemic and endangered species.

\section{Conclusions}

Our molecular findings on genetic diversity of different Adonis's species can be informative and used to explore the genetic variation pattern, population structure, and the evolutionary history of natural plant species in the future. Molecular data obtained by ITS primers can provide useful information to deal with various aspects of taxonomic classification of Adonis and the natural plant species. Along with the evolutionary process, it is known that there are some variations between species and species in plants necessitating revision studies. This paper is the first report the employing ITS primers on Adonis $\mathrm{L}$. (Ranunculaceae) for study genetic variation of various ecological sites of Turkey. In the present study, it was determined that the taxonomic classification of Adonis of the ITS sequences is highly conserved among the species in this study, supporting successfully reconstructing the phylogenies at the species level. It has been concluded that the ITS sequences of nrDNA of Adonis provide enough data to identify and classify the economically relevant species along with the distinctive structural characters. 


\section{Declarations}

Acknowledgements This study was funded by Scientific Research Commission of Hatay Mustafa Kemal University (Project No: 12580). The authors also are grateful to Dr. Z Aytaç, Dr A Kandemir, Dr. F Güneş and Dr G Akgül for helpful comments on the manuscript.

Author contributions FK and Ai conceived and designed the study; FK and Ai developed the plant material; FK, El and AT performed the DNA extraction, analyzed the ITS data; FK and KH statistical analysis; FK, EI and AT drafted the manuscript; FK, El and AT revised the manuscript. All authors agree and approved the final version of the manuscript.

Funding This study was funded by Scientific Research Commission of Hatay Mustafa Kemal University (Project No: 12580).

Conflict of interest

The authors declare that they have no conflict of interest.

\section{Ethical approval}

All samples were collected from commercial landings, and no ethical approval was required.

\section{Consent to participate}

Not applicable.

\section{Consent for publication}

All the authors agree to submit and publish an article entitled "Molecular phylogeny based on its sequences of nrDNA ITS of Adonis L. (Ranunculaceae) from various ecological sites of Turkey" in Molecular Biology Reports.

\section{References}

1. Jury SL (1978) Ranunculaceae. In: Heywood VH et al (eds) Flowering Plants of the World. Mayflower Books, New York

2. Anderson CL, Bremer K, Friis EM (2005) Dating phylogenetically basal eudicots using rbcL sequences and multiple fossil reference points. Am J Bot 92:1737-1748

3. Emadzade K, Lehnebach C, Lockhart P, Hörandl E (2010) A molecular phylogeny, morphology and classification of genera of Ranunculeae (Ranunculaceae). Taxon 59:809-828

4. Guner A, Aslan S, Ekim T, Vural M, Babac MT (2012) Türkiye Bitkileri Listesi (Damarli Bitkiler). Nezahat Go, İstanbul 
5. Christenhusz MJM, Byng JW (2016) The number of known plants species in the world and its annual increase. 261:201-217

6. Mabberley DJ (1990) The Plant Book. Cambridge University Press, New York

7. Tamura M (1990) A new classification of the family Ranunculaceae 1. Acta Phytotaxon Geobot 41:93-101

8. Wang WT (1994a) Revision of Adonis (Ranunculaceae) I. Bull Bot Res 14,1-31

9. Wang WT (1994b) Revision of Adonis (Ranunculaceae) II. Bull Bot Res 14:105-138

10. Ghorbani NM, Azizian D, Sheydaei M, Khatamsaz M (2008) Pollen morphology of some Adonis I. species (Ranunculaceae) from Iran. J Bot 14:165-170

11. Hossein-Pour A, Karahan F, İlhan E, İlçim A, Haliloğlu K (2019) Genetic structure and diversity of Adonis L. (Ranunculaceae) population collected from Turkey by inter-primer binding site (iPBS) retrotransposon markers. Turkish J Bot 17:1899-1911

12. Karahan F (2018) Türkiye Adonis L. (Ranunculaceae) cinsinin revizyonu. Hatay Mustafa Kemal Üniversitesi

13. Davis PH (1967) Adonis L. In: PH D (ed) Flora of Turkey and the East Aegean Islands, vol 1. Edinburgh Univ. Press, Edinburgh, pp 141-146

14. Hoffmann MH (1998) Plant Systematics and Evolution Ecogeographical differentiation patterns in Adonis sect. Consiligo (Ranunculaceae). PI Syst Evol 211:43-56

15. Kandemir A, Kaptaner Igcı B, Aytac Z, Fisne A (2019) Contributions to the Systematics of the Genus Adonis L. (Ranunculaceae) in Turkey. Gazi Univ J Sci 32(4):1105-1111. DOI: 10.35378/gujs.488934

16. Steinberg C (1971) Revisione sistematica e distributiva delle " adonis » annuali in italia. Webbia 25(2):299-351

17. Chan Son D, Ko C (2013) Aggregated achenes and achene morphology of the Korean Adonis L. and its related taxa in East Asia. Korean J PI Taxon 43:1-7

18. Erfanzadeh R, Kahnuj SHH, Azarnivand H, Pétillon J (2013) Comparison of soil seed banks of habitats distributed along an altitudinal gradient in northern Iran. Flora Morphol Distrib Funct Ecol Plants

19. Menemen $Y$, Uzel F (2016) Düğünçiçeğigiller (Ranunculaceae) familyasına ait bazı türlerin polen morfolojileri üzerine bir çalışma. Bağbahçe Bilim Dergisi 3:11-19

20. Heyn CC, Pazy B (1989) The annual species of Adonis (Ranunculaceae)-a polyploid complex. Plant Syst Evol 168:181-193

21. Johansson JT (1999) There large inversions in the chloroplast genomes and one loss of the chloroplast gene rps16 suggest an early evolutionary split in the genus Adonis (Ranunculaceae). Plant Syst Evol 218:133-143

22. Altay V, Karahan F, Öztürk M, Hakeem KR, Ilhan E, Erayman M (2016) Molecular and ecological investigations on the wild populations of Glycyrrhiza L. taxa distributed in the East Mediterranean Area of Turkey. J Plant Res 129:1021-1032 
23. Ilhan E, Ozgur S, Tuna GS, Eren AH, Karahan F, Tuna M, Erayman M (2017) Nuclear Dna content variation among Glycyrrhiza taxons collected from east mediterranean. 26:3251-3256

24. Ro KE, Keener CS, McPheron BA (1997) Molecular Phylogenetic Study of the Ranunculaceae: Utility of the Nuclear 26S Ribosomal DNA in Inferring Intrafamilial Relationships. Mol Phylogenet Evol 8:117-127

25. Suh Y, Lee J, Lee S, Lee C, Yeau SH, Lee NS (2002) Molecular evidence for the taxonomic identity of Korean Adonis (Ranunculaceae). J Plant Res 115:217-223

26. Cai YF, Li SW, Liu Y, Quan S, Chen M, Xie YF, Jiang HZ, Wei EZ, Yin NW, Wang L, Zhang R (2009) Molecular phylogeny of Ranunculaceae based on internal transcribed spacer sequences. Afr J Biotechnol 8:19

27. De Candolle AP (1818) Adonis. In: De Candolle AP (ed) Regni Vegetabilis Systema Naturale, vol 1. Treuttel et Wurtz, Paris, pp 220-226

28. Spach E (1839) Histoire Naturelle Des Végétaux Phanérogames. 7

29. Boissier E (1867) Flora Orientalis, vol. 1. Geneve

30. Bobrov EG (1937) Adonis. In: Komarov VL (ed) Flora of the U.S.S.R. Vol: VII. Koeltz Scientific Book, Koenigstein, pp 403-411

31. Riedl H (1963) Revision der einjährigen Arten von Adonis L. Ann des Naturhistorischen Museums Wien 66:51-90

32. Davis PH, Mill RRTK (1988) In: Davis PH, Davis PH (eds) Flora of Turkey and east Aegean Islands. Edinburgh University Press, Edinburgh, pp 177-180

33. Tutin T, Akeroyd J (1993) Adonis L. In: Tutin TO et al (eds) Flora Europaea, ed. 2, I. Cambridge University Press, Cambridge, pp 267-269

34. Guner A, Özhatay N, Ekim T, Başer KHC (2000) Flora of Turkey and the East Aegean Islands, vol 11. Edinburgh University Press, Edinburgh

35. Fu D, Robinson OR (2001) Adonis. In: Wu ZY, Raven PH, Hong DY (eds) Flora of China. Caryophyllaccae through Lardizabalaceae, vol 6. Science Press, Beijing, and Mis- souri Botanical Garden Press, SI. Louis, pp 389-391

36. Zeinalzadehtabrizi H, Hosseinpour A, Aydin M, Haliloglu K (2015) A modified genomic DNA extraction method from leaves of sunflower for PCR based analyzes. J Biodivers Environ Sci 7:222225

37. White TJ, Bruns T, Lee SJ, Taylor J (1990) Amplification and direct sequencing of fungal ribosomal RNA genes for phylogenetics. In: Innis M, Gelfand D, Sninsky J (eds) PCR protocols: a guide to methods and application. Academic Press, San Diego, pp 315-322

38. Liden M, Fukuhara T, Axberg T (1995) Phylogeny of Corydalis, ITS and morphology. Plant Syst Phylogenetic 9:183-188

39. Popp M, Erixon P, Eggens F, Oxelman B (2005) Origin and evolution of a circumpolar polyploid species complex in Silene (Caryophyllaceae) inferred from low copy nuclear RNA polymerase introns, 
rDNA, and chloroplast DNA. Syst Bot 30:302-313

40. Thompson JD, Higgins DG, Gibson TJ (1994) CLUSTAL W: improving the sensitivity of progressive multiple sequence alignment through sequence weighting, position-specific gap penalties and weight matrix choice. Nucl Acids Res 22:4673-4680

41. Letunic I, Bork P (2011) Interactive Tree of Life v2: Online annotation and display of phylogenetic trees made easy. Nucleic Acids Res 39:475-478

42. Wang W, Lu AM, Ren Y, Endress ME, Chen ZD (2009) Phylogeny and classification of Ranunculales: Evidence from four molecular loci and morphological data. Perspect Plant Ecol Evol Syst 11:81-110

43. Jabbour F, Renner SS (2012) A phylogeny of Delphinieae (Ranunculaceae) shows that Aconitum is nested within Delphinium and that Late Miocene transitions to long life cycles in the Himalayas and Southwest China coincide with bursts in diversification. Mol Phylogenet Evol 62:928-942

44. Jan T, Johansson RKJ (1993) Chloroplast DNA variation and phylogeny of the Ranunculaceae. PI Syst Evol 187:29-49

45. Fischer M, Husi R, Prati D et al (2000) RAPD variation among and within small and large populations of the rare clonal plant Ranunculus reptans (Ranunculaceae). Am J Bot 87:1128-1137

46. Mitton JB, Grant MC (1984) Associations among protein heterozygosity, growth rate and developmental homeostasis. Annu Rev Ecol Syst 15:479-499

47. Bosh M, Simon J, Molero J, Blache C (1996) Reproductuve biology, genetic variation and conservation of the rare endemic dysploid Delphinium bolosii (Ranunculaceae). Biol Conserv 86:5766

\section{Figures}



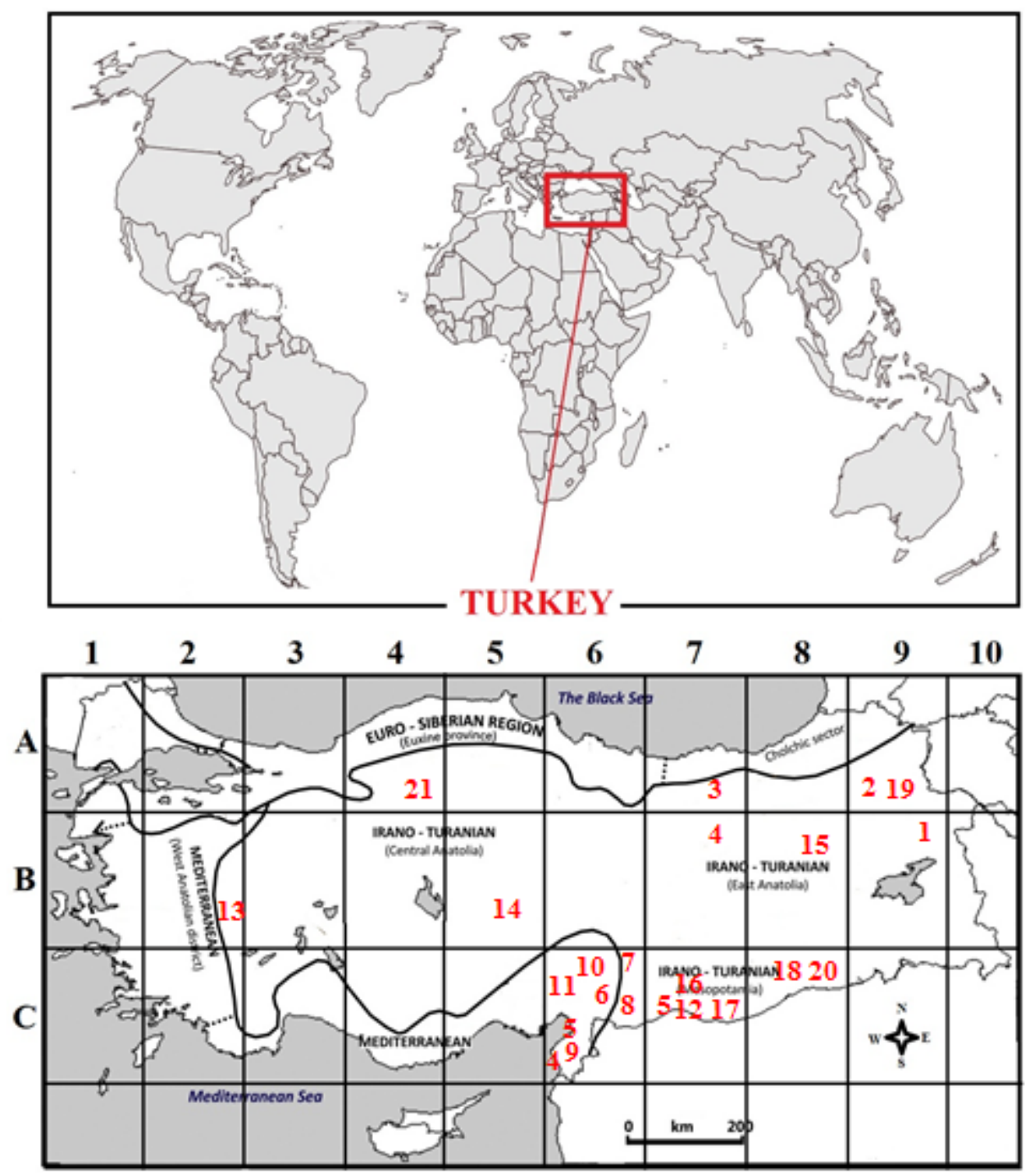

Figure 1

Geographical locations of Adonis populations in the study. 

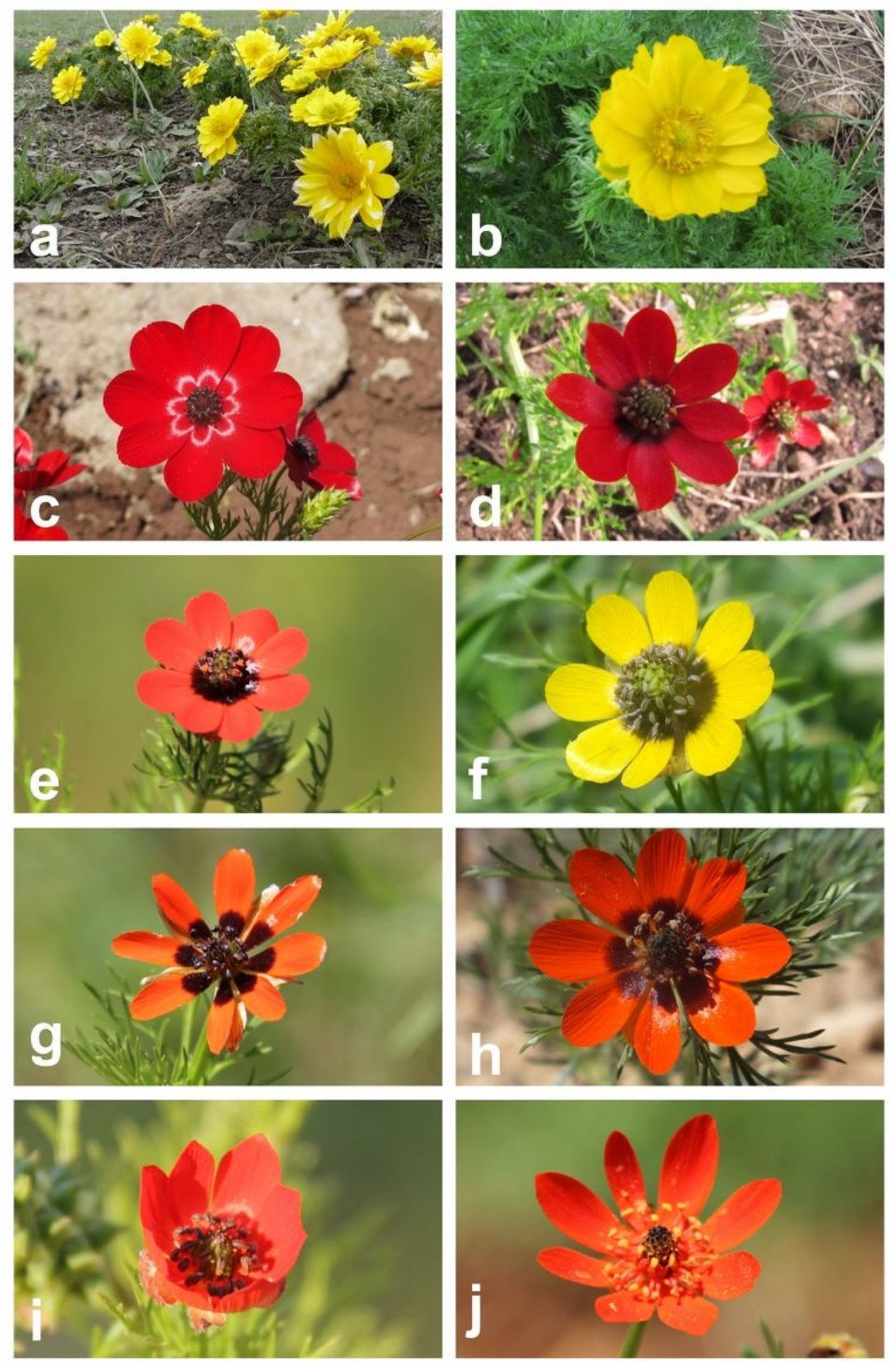

\section{Figure 2}

Enlarged view of flowers of (a) Adonis volgensis, (b) A. paryadrica, (c) A. aleppica, (d) A. annua, (e) A. microcarpa, (f), A. dentata (g), A. aestivalis ssp. aestivalis, (h) A. aestivalis ssp. parviflora (i) A. eriocalycina and (j) A. flammea 


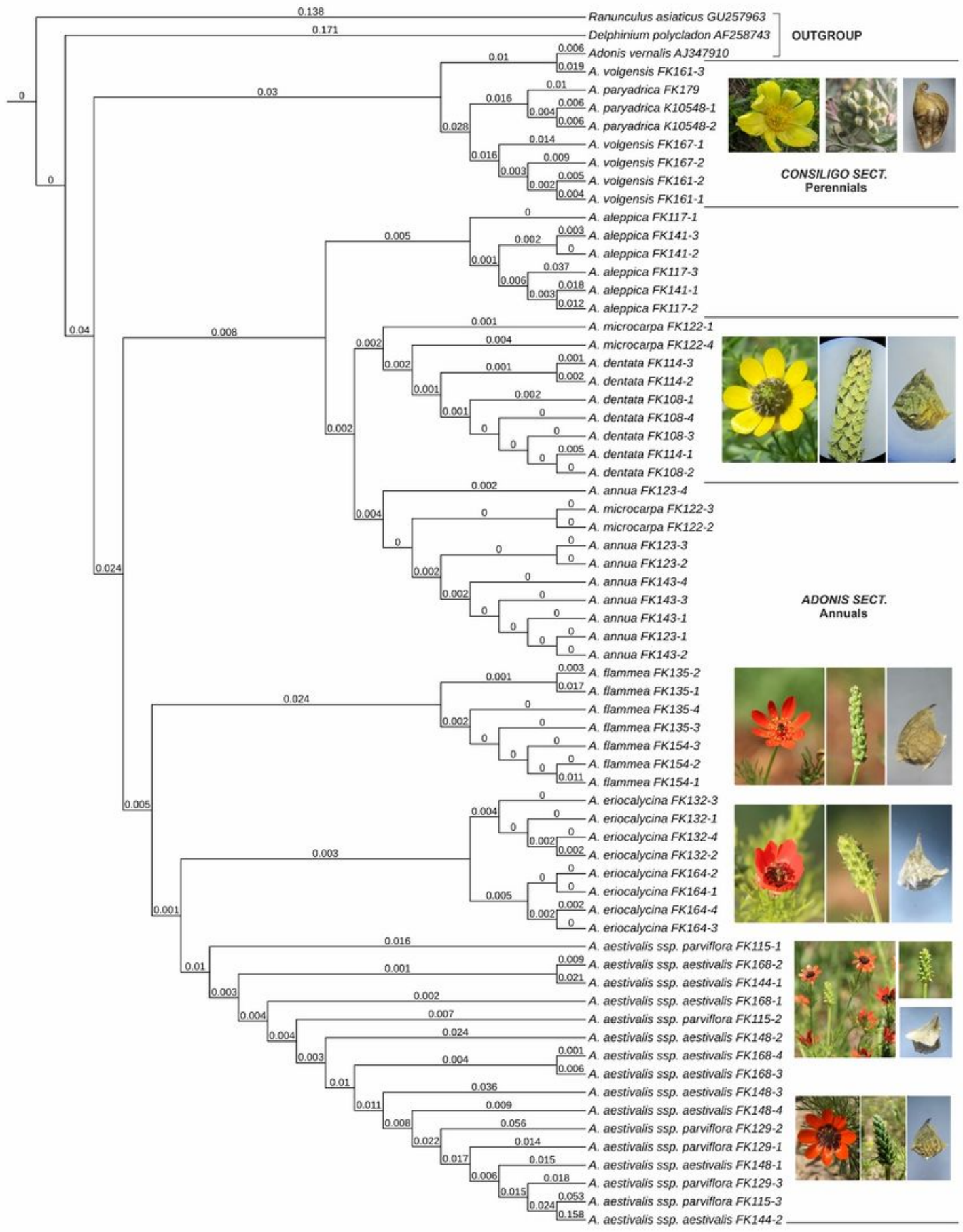

Figure 3

Pylogenetic dendrogram of Adonis ecotypes based on nrITS DNA sequences and the related sequences retrieved from NCBI GenBank

Supplementary Files 
This is a list of supplementary files associated with this preprint. Click to download.

- supplementaryfileAdonissequencei31.12.2021.docx

- supplementaryfilematrixAdonisspeciesGRCE.xIsx 